\title{
Design, synthesis and preliminary pharmacological evaluation of rigid analogues of the nicotinic agonist 1,1-dimethyl-4- phenylpiperazinium iodide (DMPP)
}

\author{
Luca Guandalini, ${ }^{a}$ Elisabetta Martini, ${ }^{a}$ Fulvio Gualtieri, ${ }^{a}$ M. Novella Romanelli, ${ }^{* a}$ and \\ Katia Varani ${ }^{b}$ \\ ${ }^{a}$ Dipartimento di Scienze Farmaceutiche, Università di Firenze, via Ugo Schiff 6, 50019 Sesto \\ Fiorentino (FI), Italy, and \\ ${ }^{b}$ Dipartimento di Farmacologia, Università di Ferrrara, via Fossato di Mortara 17-19, 44100 \\ Ferrara, Italy \\ E-mail: novella.romanelli@,unifi.it
}

\author{
Dedicated to Prof. Vincenzo Tortorella on the occasion of his "Fuori Ruolo" status \\ (received 17 Dec 03; accepted 04 Apr 04; published on the web 05 Apr 04)
}

\begin{abstract}
Some frozen analogues of 1,1-dimethyl-4-phenylpiperazinium iodide (DMPP) and of 1-(3pyridyl)piperazine have been synthesized and tested on rat cerebral cortex by means of binding studies. Among the synthesized substances, only compound 2c was found to displace $\left.{ }^{3} \mathrm{H}\right]-$ cytisine from the nicotinic binding sites on rat cerebral cortex. Some possible explanations for the inactivity of the other compounds are given.
\end{abstract}

Keywords: Nicotinic receptors ligands, tetrahydropyrazino[1,2-a]indoles, hexahydropyrazino[1,2-a]indoles, tetrahydropyrido $\left[4^{\prime}, 3^{\prime}: 4,5\right]$ pyrrolo[1,2-a]pyrazines

\section{Introduction}

Nicotinic acetylcholine receptors (nAChRs) are ligand-gated ion channels which modulate synaptic transmission. They are formed by five subunits arranged to form a pore, through which cations cross the cellular membrane. To date, 17 different subunits have been identified in vertebrate species, and according to the subunit composition, location, and sensitivity to $\alpha$ bungarotoxin $(\alpha \mathrm{BTX})$, they can be classified into different groups: 1) muscle-type receptors, found at the skeletal neuromuscular junction and in the electric organs of Torpedo fishes, formed by four different subunits $(\alpha 1, \beta 1, \gamma, \delta$ or $\alpha 1, \beta 1, \varepsilon, \delta)$; $2 \alpha \mathrm{BTX}$-insensitive neuronal receptors, found in the peripheral and central nervous systems, formed by different combinations of $\alpha$ 2-6 and $\beta$ 2-4 subunits; 3) $\alpha$ BTX-sensitive neuronal receptors, found in the CNS, containing $\alpha 7-10$ subunits. According to a recent classification, the subtypes formed by the most recently identified subunits ( $\alpha 9$ and $\alpha 10$ ), which are expressed primarily in sensory epithelia, form a separate group. ${ }^{1}$ 
There is great interest in nAChRs, since they seem to be involved in several physiological functions, such as synaptic transmission, modulation of presynaptic transmitter release, cognitive processes and control of movement in normal subjects, as well as in several pathological processes. In fact, dysfunction of $\mathrm{nAChR}$ has been linked to a number of human diseases such as depression, schizophrenia, Alzheimer's and Parkinson's diseases, Tourette's syndrome. ${ }^{2}$ Moreover, some genetic forms of epilepsy (ADNFLE) and congenital myasthenic syndrome are associated to mutations in the gene coding for nAChR subunits. ${ }^{3-5}$ Other therapeutically important applications of nicotinic ligands are the treatment of nicotine addiction and the management of pain. ${ }^{6}$

For a long time the nicotinic receptor extracted from Torpedo fishes has been studied using electron microscopy to obtain valuable information about the structure and functioning of the receptor, ${ }^{7-10}$ but an important step toward the understanding of nAChR structure has come from the resolution of X-ray crystallography of the molluscan acetylcholine-binding protein $(\mathrm{AChBP})^{11}$ which has been used to model the extracellular domain of the nicotinic receptor where the agonist binding site is located. ${ }^{12-14} \mathrm{~A}$ three-dimensional model of the binding site is helpful to the design of new ligands; so far, nicotinic ligands have been designed using qualitative pharmacophoric models and 3D-QSAR analysis. ${ }^{15-20}$ The nicotinic pharmacophore is formed by two groups: an H-bond acceptor atom, usually a pyridyl nitrogen or a carbonyl oxygen, and a positive nitrogen, which can be protonated or quaternarized; the proposed distance between these two groups ranges from $4.5 \AA^{15}$ to $5.5 \AA \AA^{16,21}$

As a part of our research in the field of nicotinic ligands, we have recently reported the synthesis and pharmacological evaluation of a series of analogues of 1,1-dimethyl-4phenylpiperazinium iodide (DMPP) ${ }^{22,23}$ (general formula A, Figure 1),

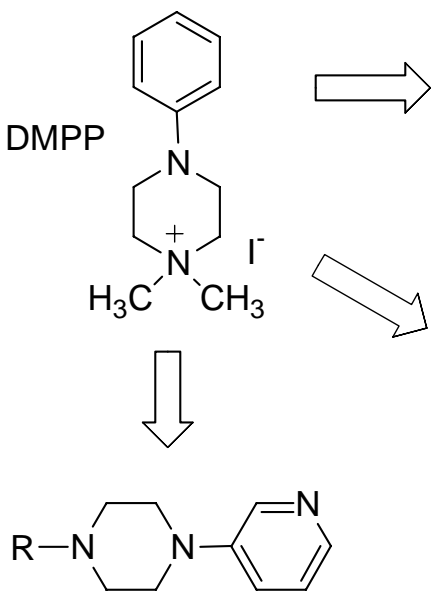

1a: $\mathrm{R}=\mathrm{H}$;

1b: $\mathrm{R}=\mathrm{CH}_{3}$

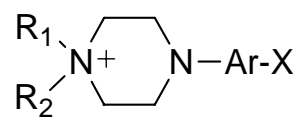

A

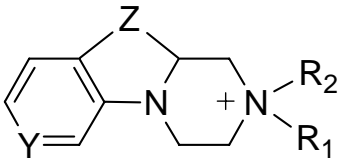

B

2a-c: $Z=\mathrm{CH}, \mathrm{Y}=\mathrm{CH}$

3a,b: $Z=\mathrm{CH}, Y=N$,

4a-c: $Z=\mathrm{CH}_{2}, Y=\mathrm{CH}$,

$$
\begin{gathered}
\mathrm{X}=\mathrm{H}, \mathrm{OH}, \mathrm{NH}_{2}, \mathrm{OMe}, \mathrm{NO}_{2} \\
\mathrm{OAc}, \mathrm{CH}_{3} \text {, halogen } \\
\mathrm{Ar}=\mathrm{Ph}, \text { Pyridine, Pyridazine } \\
\mathrm{R}_{1}, \mathrm{R}_{2}=\mathrm{H}, \mathrm{CH}_{3}
\end{gathered}
$$

$$
\begin{aligned}
& \mathrm{Z}=\mathrm{CH}, \mathrm{CH}_{2}, \\
& \quad \text { alkyl chain } \\
& \mathrm{Y}=\mathrm{CH}, \mathrm{N} \\
& \mathrm{R}_{1}, \mathrm{R}_{2}=\mathrm{H}, \mathrm{CH}_{3}
\end{aligned}
$$

a: $R_{1}, R_{2}=H$

b: $\mathrm{R}_{1}=\mathrm{H}, \mathrm{R}_{2}=\mathrm{CH}_{3}$

c: $\mathrm{R}_{1}, \mathrm{R}_{2}=\mathrm{CH}_{3}$

\section{Figure 1}

A well-known nicotinic agonist which, lacking the H-bond acceptor group, does not fit the proposed nicotinic pharmacophore. DMPP is reported to bind to the central nicotinic receptor with $\mathrm{K}_{\mathrm{i}}$ values ranging from $57 \mathrm{nM}^{24}$ to $250 \mathrm{nM} ;{ }^{22}$ it has been shown ${ }^{23}$ that the introduction of 
substituents on the phenyl ring greatly improved affinity but in general, derivatives with a permanent positive charge showed higher potency than their tertiary amino analogues. However, by introducing an $\mathrm{H}$-bond forming group $\left(\mathrm{NH}_{2}, \mathrm{~F}, \mathrm{OCOMe}, \mathrm{NO}_{2}\right)$ in position 3 on the phenyl ring, or by replacing the phenyl ring with $\mathrm{N}$-containing heterocycles, compounds were synthesized endowed with good affinity for the nicotinic receptor also as uncharged amines.

Since the possibility to cross the blood brain barrier is a crucial feature for drugs in the treatment of CNS pathologies, we decided to focus our attention on the uncharged 1-(3pyridyl)lpiperazines $\mathbf{1 a}$ and $\mathbf{1 b}$ (Figure 1), endowed with good affinity $\left(\mathrm{K}_{\mathrm{i}} 90 \mathrm{nM}\right)$. In these molecules, as well as in DMPP, the rotation around the arylpiperazine bond is free; this observation prompted us to evaluate the effect on affinity, and eventually selectivity, of reducing the conformational freedom of this part of the molecule. Therefore, the compounds of general formula B (Figure 1) were designed, in which the two cycles (aromatic and piperazine rings) are connected through a suitable spacer $(Z)$ that fixes their relative orientation.

This modification of the structure of DMPP and analogues could also help to find the bioactive conformation of this class of molecules. In fact, the conformational analysis of these molecules using different computational methods ends up with different low-energy conformations. As pointed out by Dijsktra, ${ }^{25}$ the quantum mechanical semiempirical program AM1 yields a conformation of DMPP similar to that found in the crystal structure, ${ }^{26}$ with the dihedral angle $\left(\mathrm{C}_{2},-\mathrm{C}_{1},-\mathrm{N}-\mathrm{lp}\right.$, Figure 2$)$ at $120^{\circ}$.

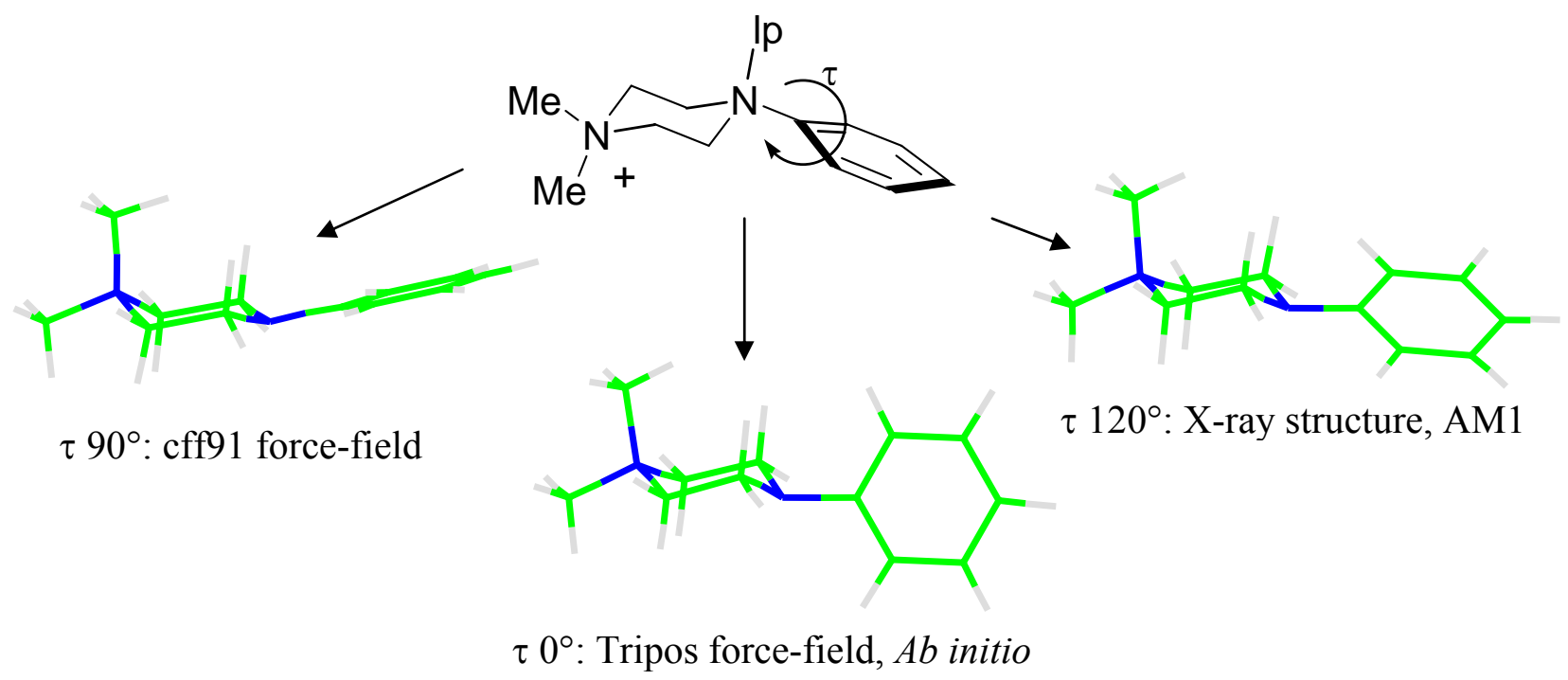

Figure 2. Low-energy conformation of DMPP, calculated with different methods. Hydrogen atoms are shown in gray, carbon atoms in green, nitrogen atoms in blue.

This minimum energy conformation has been explained by the presence of two opposite factors: the possibility of conjugation between the nitrogen lone pair and the $\pi$ orbitals, and the steric hindrance between the aromatic ring and the methylene groups of the piperazine ring. ${ }^{25,26}$ Other computational methods produce different results: ab initio (HF) gives a conformation in which the two rings, phenyl and piperazine, are orthogonal $\left(\tau 0^{\circ}\right)$, while molecular mechanics 
calculations give different results according to the force-field used: a conformation with $\tau 90^{\circ}$ (cff91 force-field within the Accelrys program Discover) and a conformation with $\tau 0^{\circ}$ (Tripos force-field).

Compounds of general formula $\mathbf{B}$, with $\mathrm{Z}$ being only a one-carbon unit, should mimic the $\tau$ $90^{\circ}$ conformation, while the orthogonal conformation could be approached with $\mathrm{Z}$ being a longer saturated alkyl chain.

We decided to start with $Z$ being only a one-carbon unit, synthesizing 1,2,3,4-tetrahydropyrazino[1,2-a]indoles (2a-c, $\mathrm{Y}=\mathrm{CH}, \mathrm{Z}=\mathrm{CH}$ ), their aza-analogues 1,2,3,4-tetrahydropyrido[4',3':4,5]pyrrolo[1,2-a]pyrazine (3a,b, $\mathrm{Y}=\mathrm{N}, \mathrm{Z}=\mathrm{CH}$ ), and their hydrogenated derivatives 1,2,3,4,10,10a-hexahydropyrazino[1,2-a]indoles (4a-c, $\mathrm{Y}=\mathrm{CH}, \mathrm{Z}=\mathrm{CH}_{2}$ ). Both secondary and tertiary amines $\left(\mathrm{R}=\mathrm{H}, \mathrm{CH}_{3}\right)$ and, when possible, also the corresponding methiodides were synthesized. In fact, although as mentioned before, compounds carrying a permanent positive charge are not suitable to be developed as drugs, if endowed with good affinity they can be useful as pharmacological tools to study the geometry of ligand interaction and to characterize nAChRs subtypes.

\section{Results and Discussion}

\section{Chemistry}

The synthesis of the 1,2,3,4-tetrahydropyrazino[1,2-a]indoles 2 started from the commerciallyavailable ethyl indole-2-carboxylate which was reacted with chloroacetonitrile obtaining compound 5 (Scheme 1). ${ }^{27}$

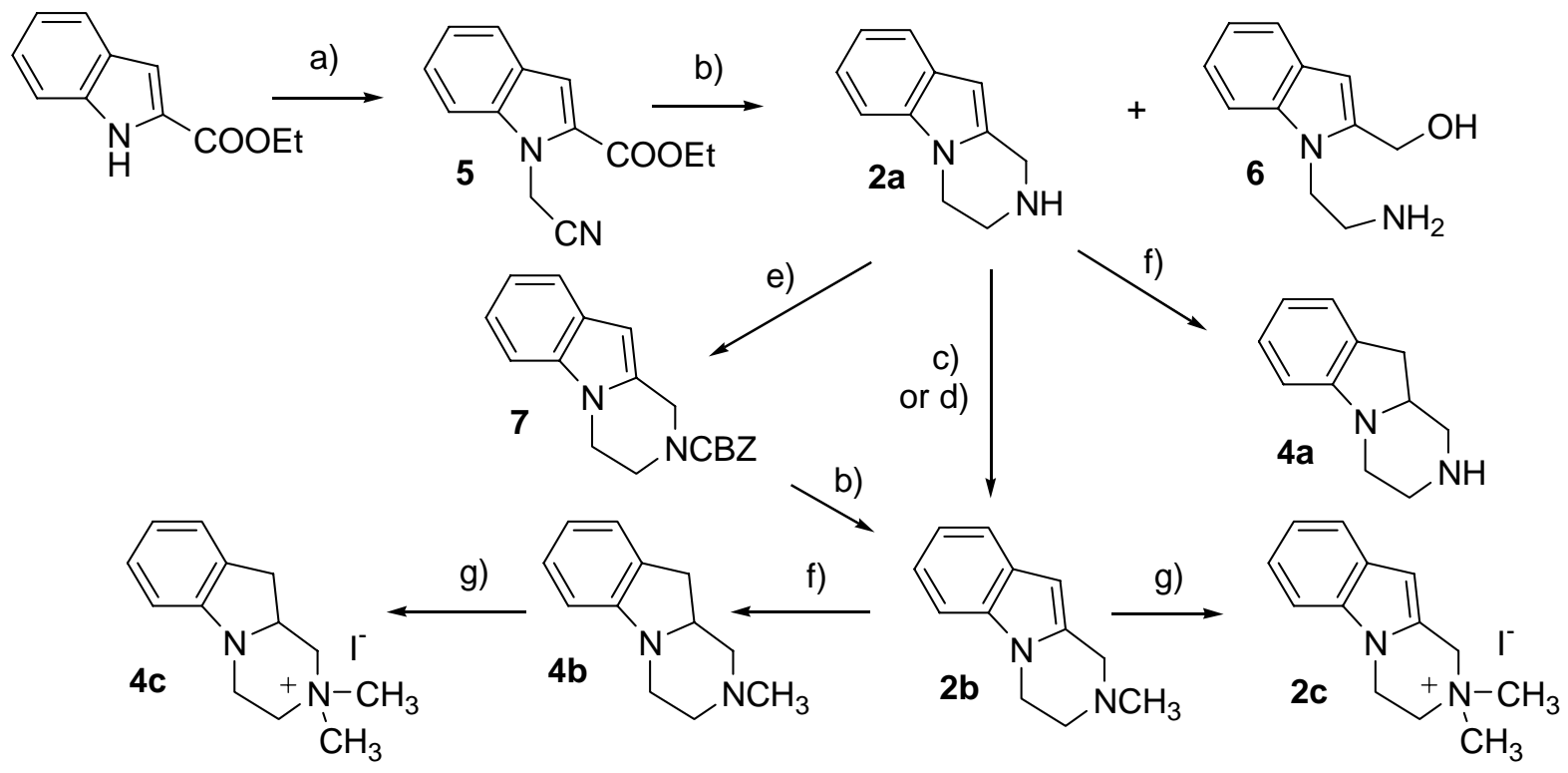

a) t-BuOK, $\mathrm{ClCH}_{2} \mathrm{CN}$; b) $\mathrm{LiAlH}_{4}$; c) $\left(\mathrm{CH}_{2} \mathrm{O}\right) \mathrm{n}, \mathrm{H}_{2} / \mathrm{Pd} / \mathrm{C}$; d) Mel (1 eq), DMF; e) $\mathrm{ClCOOCH}_{2} \mathrm{Ph}$; f) $\left.\mathrm{NaBH}_{3} \mathrm{CN}, \mathrm{MeOH} ; \mathrm{g}\right) \mathrm{Mel}, \mathrm{Et}_{2} \mathrm{O}$.

\section{Scheme 1}


Treatment of 5 with $\mathrm{LiAlH}_{4}$ resulted in the reduction of both the cyano and the ester functions with cyclization, giving $2 \mathbf{a}^{28}$ in moderate yield $(24 \%)$ and in mixture with the aminoalcohol 6 (20\%), which were separated by chromatography.

Methylation of 2a was first attempted by reacting the secondary amine with formaldehyde and formic acid, but only decomposition of the starting material was observed. Treatment with paraformaldehyde in a Parr apparatus under hydrogen pressure and in the presence of $\mathrm{Pd} / \mathrm{C}$, according to Abreo, ${ }^{21}$ gave the expected product $2 \mathbf{b}^{28}$ in very low yield $(10 \%)$, while MeI in DMF gave slightly better results (31\% yield). Finally, treatment of $2 \mathbf{a}$ with benzyl chloroformate gave 7, which was then reduced with $\mathrm{LiAlH}_{4}$ affording $\mathbf{2 b}$ with good yield. Compounds $2 \mathbf{a}$ and 2b were successfully reduced with $\mathrm{NaBH}_{3} \mathrm{CN}$ in acetic acid ${ }^{29}$ obtaining the corresponding 1,2,3,4,10,10a-hexahydropyrazino[1,2-a]indoles $\mathbf{4} \mathbf{a}^{30}$ and $\mathbf{4 b}$. Methiodides $\mathbf{2} \mathbf{c}$ and $\mathbf{4} \mathbf{c}$ were then obtained by treatment with MeI in ether.

For the synthesis of 1,2,3,4-tetrahydropyrido[4',3':4,5]pyrrolo[1,2-a]pyrazines 3 , an analogous synthetic pathway was first attempted (Scheme 2). Compound $\mathbf{1 0}$ was prepared according to Fisher: ${ }^{31}$ the commercially available 4-methyl-3-nitropyridine was treated with diethyl oxalate and sodium ethoxide obtaining ethyl 3-(3-nitropyridin-4-yl)-2-oxo-propionate (8), which was hydrogenated in a Parr apparatus to 10. Through this pathway, compound $\mathbf{1 0}$ was usually obtained in good yield, but sometimes, when scaling up the reaction, hydrogenation stopped at the hydroxylamine derivative $\mathbf{9}$, which was isolated and further hydrogenated obtaining 10. The azaindole derivative 10 was then alkylated obtaining the nitrile 11, but subsequent reduction with $\mathrm{LiAlH}_{4}$ gave 3a in very low yield together with the aminoalcohol 12.

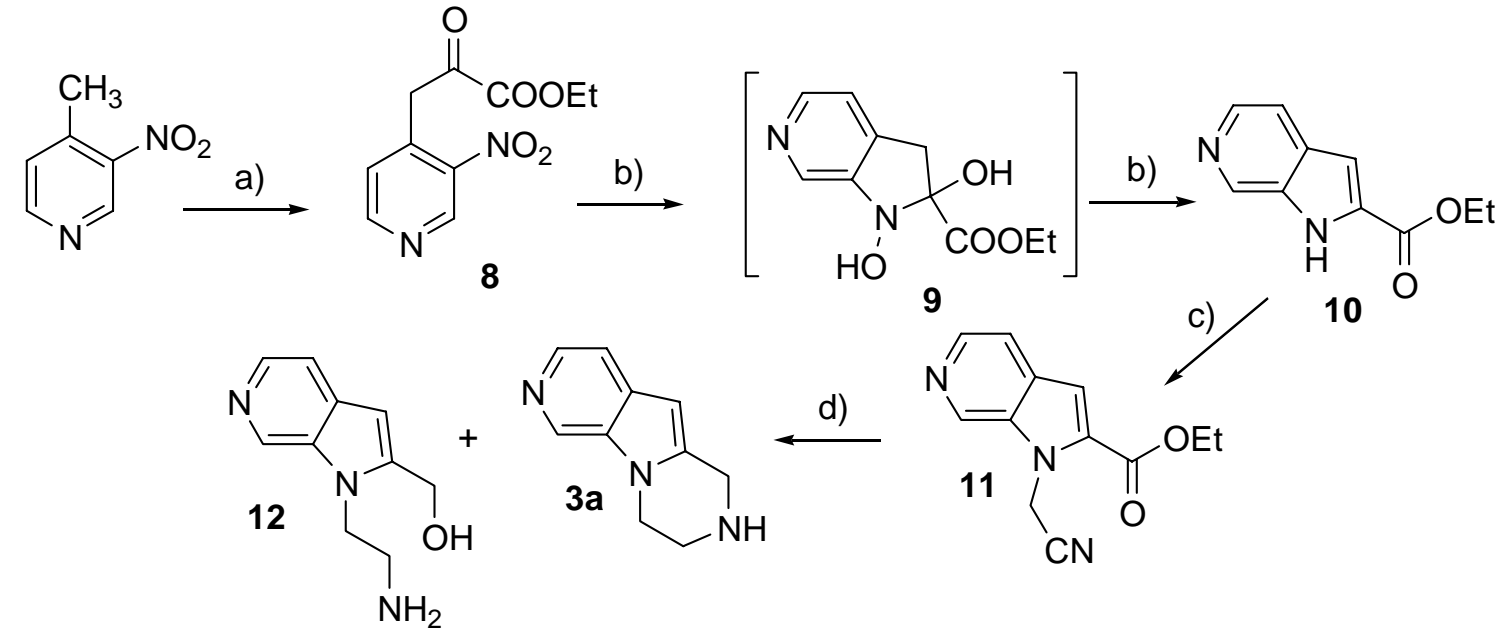

a) diethyl oxalate, EtONa; b) $\mathrm{H}_{2} / \mathrm{Pd} / \mathrm{C}$; c) t-BuOK, $\mathrm{ClCH}_{2} \mathrm{CN}$; d) $\mathrm{LiAlH}_{4}$

\section{Scheme 2}

Therefore, we decided to reduce $\mathbf{1 1}$ in two steps (scheme 3): the reaction with Raney/Ni gave the lactam 13 which was reduced with $\mathrm{LiAlH}_{4}$ to $3 \mathbf{a}$, however without substantial improvement in the yields. To obtain the tertiary amine $\mathbf{3 b}$, 3a was treated with benzyl chloroformate to give 14 which was then reduced with $\mathrm{LiAlH}_{4}$ obtaining $3 \mathbf{b}$. Subsequent methylation with MeI failed to give the desired methiodide $\mathbf{3 c}$, and $\mathbf{1 5}$ was obtained as the only product. 


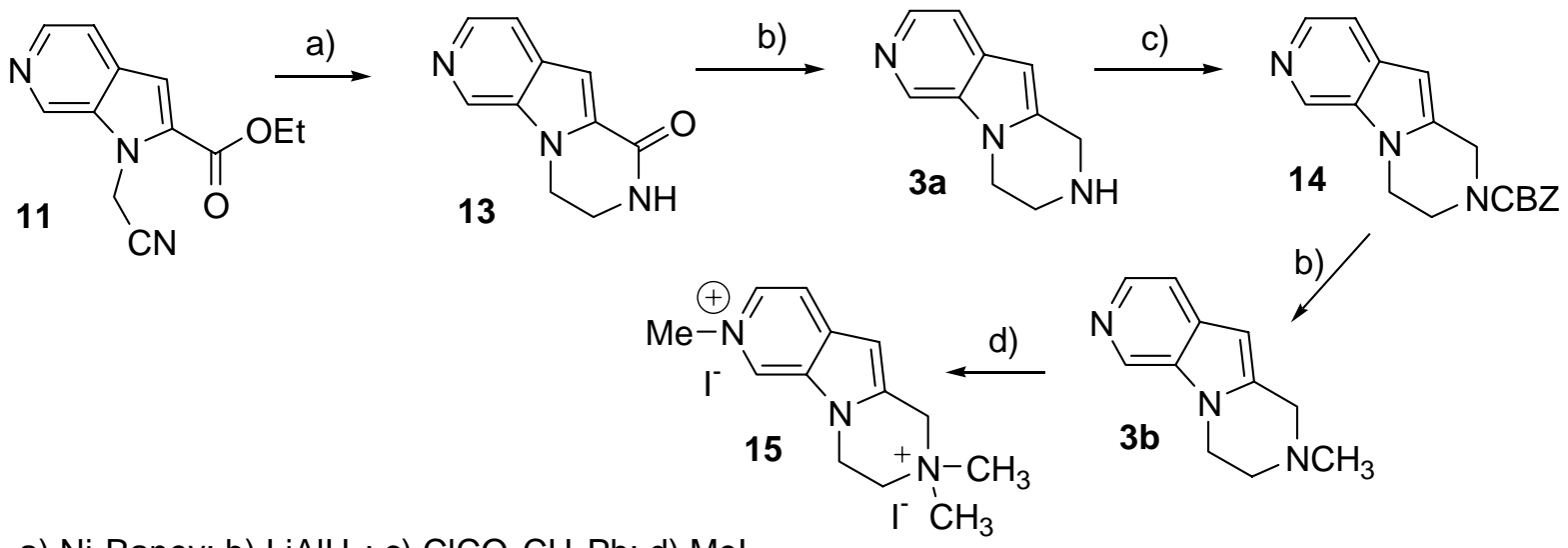

a) Ni-Raney; b) $\mathrm{LiAlH}_{4}$; c) $\mathrm{ClCO}_{2} \mathrm{CH}_{2} \mathrm{Ph}$; d) Mel.

\section{Scheme 3}

\section{Biological evaluation}

Compounds 2-4 were tested in vitro on rat brain homogenates to evaluate their affinity for the central nicotinic receptors, according to a previously reported experimental protocol. ${ }^{23}\left[{ }^{3} \mathrm{H}\right]-$ Cytisine was used as radioligand; this compound is reported to label the $\alpha 4 \beta 2$ subtype, which is believed to represent up to $90 \%$ of the high affinity agonist binding site in the brain. ${ }^{32} 33$

Among the frozen analogues of DMPP and of 3-pyridylpiperazine (compounds 2a-c, 4a-c, 3a and $\mathbf{3 b}$ ), only methiodide 2c shows affinity for the central nicotinic receptor with $\mathrm{K}_{\mathrm{i}} 2.02 \mu \mathrm{M}$ (confidence limits 1.24-3.29 $\mu \mathrm{M}$ ); the other compounds do not displace $\left[{ }^{3} \mathrm{H}\right]$-cytisine from rat cerebral cortex up to a $100 \mu \mathrm{M}$ concentration.

As far as the piperazino-indoles are concerned, the lack of affinity of secondary bases (2a and $\mathbf{4 a}$ ) and tertiary bases (2b and $\mathbf{4 b}$ ) is not surprising, since also 1-phenyl-4-methylpiperazine (the tertiary base of DMPP) is devoid of affinity. ${ }^{23}$ On the contrary, it seems that the freezing of the phenylpiperazinium moiety into a tricyclic structure is detrimental for activity, since the methiodide 4c does not interact with the receptor, and the affinity of compound 2c is 8-fold lower than that of DMPP. The lack of affinity of the aza compounds $\mathbf{3 a}$ and $\mathbf{3} \mathbf{b}$ is also unexpected, since the parent compounds $\mathbf{1 a}$ and $\mathbf{1 b}$ show $\mathrm{K}_{\mathrm{i}}$ values in the nanomolar range.

Some explanations regarding the inactivity of compounds 3-4 are however possible. The conformation of DMPP and of $\mathbf{1}(\mathbf{a}, \mathbf{b})$, which have been constrained, respectively, into the hexahydropyrazino[1,2-a]indole $\mathbf{4 c}$ and the tetrahydropyrido[4',3':4,5]pyrrolo[1,2-a]pyrazines 3(a,b), may not be the right one. In this way, in fact, the molecules have been frozen into a pseudoplanar conformation, with a value of the dihedral angle $\tau$ of $90^{\circ}$ (Figure 2), which may not be the bioactive conformation. In this respect, the synthesis of substances (general formula $\mathbf{B}$, Figure 1) in which the central five-membered ring has been replaced by a larger ring that allows a more orthogonal disposition between the aromatic and the piperazine rings will help to clarify this point.

On the other hand, a limiting factor in the interaction of these molecules with the receptor may be the space available at the binding site. In fact, $2 \mathbf{c}\left(\mathrm{K}_{\mathrm{i}} 2.02 \mu \mathrm{M}\right)$ and $4 \mathbf{c}(\mathrm{Ki}>100 \mu \mathrm{M})$, differing for the double/single bond within the indole ring, show a difference in their volume of $4.58 \AA^{3}$. In this respect, it must be noticed that also 1,1,3-trimethyl-4-phenylpiperazinium iodide 
(the 3-methyl analogue of DMPP) ${ }^{23}$ is completely devoid of affinity. In addition, the reduction of the indole double bond, while reducing the surface of the aromatic part, induces a bending in the molecule (Figure 3) which may not be compatible with the space available at the binding site.
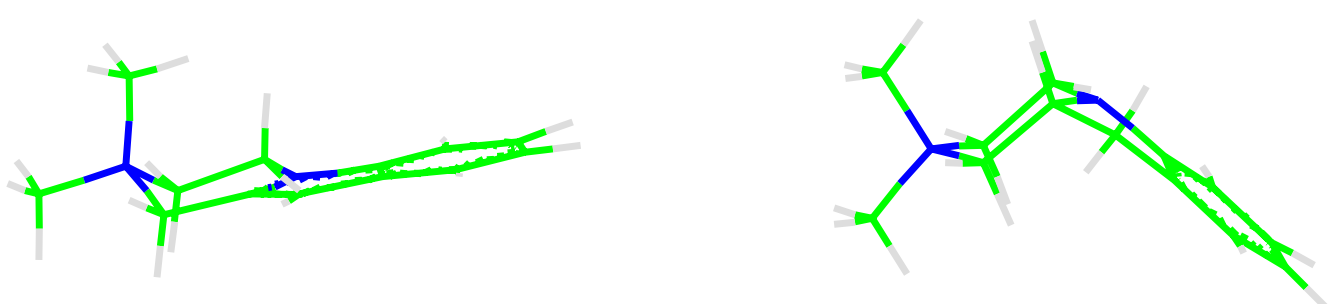

Figure 3. Minimized conformations of compound 2c (left) and 4c (right). Hydrogen atoms are shown in gray, carbon atoms in green, nitrogen atoms in blue.

A further consideration can be made regarding compounds $\mathbf{3 a}$ and $\mathbf{3 b}$. One reason for their lack of affinity could be the wrong orientation of the pyridyl nitrogen in the binding site; in fact, in 1,2,3,4-tetrahydropyrido[4',3':4,5]pyrrolo[1,2-a]pyrazines $\mathbf{B}$ the pyridyl ring has been constrained into one of the two possible "planar" conformations. In this respect, the synthesis of the isomeric 6,7,8,9-tetrahydropyrido[2',3':4,5]pyrrolo[1,2-a]pyrazines $\mathbf{C}$ (Figure 4), which is on the way, may help to clarify this point.
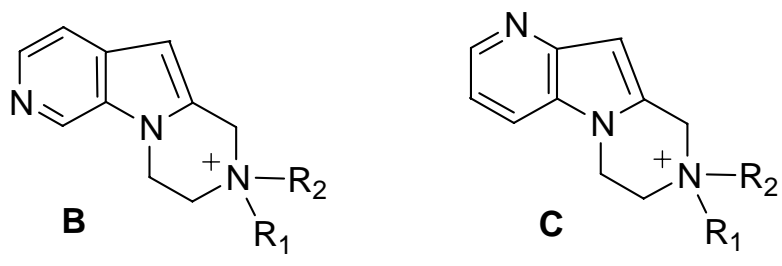

Figure 4

\section{Conclusions}

Some frozen analogues of 1,1-dimethyl-4-phenylpiperazinium iodide (DMPP) and of 1-(3pyridyl)piperazine (1a and $\mathbf{1 b}$ ) have been synthesized and tested on rat cerebral cortex by means of binding studies. Compound 2c shows an 8-fold lower affinity for the nicotinic receptor than the lead compound DMPP; the other compounds do not interact with the nicotinic receptor. The decrease or lack of affinity of these compounds suggests that the structures in which the lead compounds have been frozen do not represent their bioactive conformations, or their volume is not compatible with the space available within the interaction site. The synthesis of other frozen analogues may help to clarify the bioactive conformation of aryl piperazine. 


\section{Experimental section}

General Procedures. All melting points were taken on a Büchi apparatus and are uncorrected. Infrared spectra were recorded with a Perkin-Elmer 681 spectrophotometer in a Nujol mull for solids and neat for liquids. Unless otherwise stated, NMR spectra were recorded on a Gemini 200 spectrometer. Chromatographic separations were performed on a silica gel column by gravity chromatography (Kieselgel 40, 0.063-0.200 mm, Merck) or flash chromatography (Kieselgel 40, 0.040-0.063 mm, Merck). Yields are given after purification, unless otherwise stated. Where analyses are indicated by symbols, the analytical results are within $\pm 0.4 \%$ of the theoretical values.

Ethyl 1-cyanomethyl-1H-indole-2-carboxylate (5). ${ }^{27}$ To a solution of ethyl indole-2carboxylate $(1.2 \mathrm{~g}, 6.34 \mathrm{mmol})$ in anhydrous DMF $(15 \mathrm{~mL})$ potassium tert-butoxide $(1.06 \mathrm{~g}$, $9.4 \mathrm{mmol})$ was added at room temperature. After $40 \mathrm{~min}$, chloroacetonitrile $(0.8 \mathrm{~mL}, 12.6 \mathrm{mmol})$ was added dropwise and the solution heated at $65{ }^{\circ} \mathrm{C}$ for $30 \mathrm{~min}$ and left stirring at room temperature for $20 \mathrm{~h}$. Water $(20 \mathrm{~mL})$ was then added and all the solvents distilled to give a solid residue that was treated with water and extracted with $\mathrm{CH}_{2} \mathrm{Cl}_{2}$. Drying $\left(\mathrm{Na}_{2} \mathrm{SO}_{4}\right)$ and removal of the solvent gave 1 of $.41 \mathrm{~g}$ the title compound (white solid, 97\% yield). Mp 98-99 ${ }^{\circ} \mathrm{C} .{ }^{1} \mathrm{H}-\mathrm{NMR}$ $\left(\mathrm{CDCl}_{3}, \delta\right): 1.44\left(\mathrm{t}, 3 \mathrm{H}, J=7.2 \mathrm{~Hz}, \mathrm{CH}_{3} \mathrm{CH}_{2} \mathrm{O}\right) ; 4.43\left(\mathrm{q}, 2 \mathrm{H}, J=7.2 \mathrm{~Hz}, \mathrm{CH}_{3} \mathrm{CH}_{2} \mathrm{O}\right) ; 5.62(\mathrm{~s}, 2 \mathrm{H}$, $\left.\mathrm{CH}_{2} \mathrm{CN}\right) ; 7.23-7.31(\mathrm{~m}, 1 \mathrm{H}), 7.41-7.48(\mathrm{~m}, 3 \mathrm{H}), 7.73(\mathrm{~d}, 1 \mathrm{H}, J=8.1 \mathrm{~Hz}$ ) (aromatic protons) ppm. ${ }^{13} \mathrm{C}-\mathrm{NMR}\left(\mathrm{CDCl}_{3}\right)$ ): $14.43(\mathrm{q}), 32.46(\mathrm{t}), 61.32(\mathrm{t}), 109.67$ (d), 112.67 (d), $115.07(\mathrm{~s}), 122.05$ (d), 123.23 (d), 126.42 (d), 126.42 (s), 126.67 (s), 138.71 (s), 161.87 (s) ppm.

1,2,3,4-Tetrahydropyrazino[1,2-a]indole (2a) ${ }^{28} \mathrm{LiAlH}_{4}(2.41 \mathrm{~g}, 63.4 \mathrm{mmol})$ was suspended in $15 \mathrm{~mL}$ of dry DME and a solution of $5(4.4 \mathrm{~g}, 19.3 \mathrm{mmol})$ in $20 \mathrm{~mL}$ of dry DME was added dropwise at room temperature. The mixture was heated at $50{ }^{\circ} \mathrm{C}$ for $7 \mathrm{~h}$. After cooling, the excess of hydride was destroyed with ice and the solvent evaporated. The residue was dissolved in AcOEt and extracted with acidic water, the aqueous phase alkalinized and extracted with AcOEt. The organic phase was dried and evaporated and the residue separated by flash chromatography $\left(\mathrm{CHCl}_{3} /\right.$ petroleum ether/Et $2 \mathrm{O} / \mathrm{EtOH} / \mathrm{NH}_{3} \quad 360 / 900 / 360 / 180 / 9.9$ as first eluent and $\mathrm{CH}_{2} \mathrm{Cl}_{2} /$ petroleum ether/EtOH/ $/ \mathrm{NH}_{3} 340 / 60 / 65 / 8$ as second eluent): $0.79 \mathrm{~g}$ of $2 \mathbf{2 a}$ (low melting solid, $23.8 \%$ yield) and $0.75 \mathrm{~g}$ of [1-(2-aminoethyl)-1H-indol-2-yl]-methanol (6). (oil, $20.4 \%$ yield).

6. ${ }^{1} \mathrm{H}-\mathrm{NMR}\left(\mathrm{CDCl}_{3}, \delta\right): 2.97$ (bs, $\left.2 \mathrm{H}, \mathrm{OH} / \mathrm{NH}\right) ; 3.14\left(\mathrm{t}, 2 \mathrm{H}, J=5.1 \mathrm{~Hz}, \mathrm{CH}_{2} \mathrm{NH}_{2}\right) ; 4.26$ (t, $2 \mathrm{H}, J$ $\left.=5.1 \mathrm{~Hz}, \mathrm{NCH}_{2} \mathrm{CH}_{2} \mathrm{NH}_{2}\right) ; 4.73\left(\mathrm{~s}, 2 \mathrm{H}, \mathrm{CH}_{2} \mathrm{OH}\right) ; 6.50(\mathrm{~s}, 1 \mathrm{H}), 7.09-7.31(\mathrm{~m}, 3 \mathrm{H}), 7.63(\mathrm{~d}, 1 \mathrm{H}, J$ $=7.3 \mathrm{~Hz}$ ) (aromatic protons) ppm. ${ }^{13} \mathrm{C}-\mathrm{NMR}\left(\mathrm{CDCl}_{3}\right) \delta: 39.60(\mathrm{t}), 45.63(\mathrm{t}), 55.83(\mathrm{t}), 101.62$ (d), 109.34 (d), 119.89 (d), 121.16 (d), 121.76 (d), 127.90 (s), 136.37 (s), 140.55 (s) ppm. IR (neat) $v 3295,3360\left(\mathrm{NH}_{2}\right) \mathrm{cm}^{-1}$. Anal. Calcd for $\mathrm{C}_{11} \mathrm{H}_{14} \mathrm{~N}_{2} \mathrm{O}: \mathrm{C}, 69.45 ; \mathrm{H}, 7.42 ; \mathrm{N}, 14.73$. Found: C, 69.70; H, 7.53; N, 14.56.

2a. ${ }^{1} \mathrm{H}-\mathrm{NMR}\left(\mathrm{CDCl}_{3}, \delta\right): 1.82$ (bs, $\left.1 \mathrm{H}, \mathrm{NH}\right) ; 3.36$ (t, $\left.2 \mathrm{H}, J=5.7 \mathrm{~Hz}, \mathrm{CH}_{2} \mathrm{CH}_{2} \mathrm{NH}\right) ; 4.02$ (t, $2 \mathrm{H}, J$ $\left.=5.7 \mathrm{~Hz}, \mathrm{CH}_{2} \mathrm{CH}_{2} \mathrm{NH}\right) ; 4.23\left(\mathrm{~s}, 2 \mathrm{H}, \mathrm{CCH}_{2} \mathrm{NH}\right) ; 6.21(\mathrm{~s}, 1 \mathrm{H}), 7.08-7.31(\mathrm{~m}, 3 \mathrm{H}), 7.58(\mathrm{~d}, 1 \mathrm{H}, J=$ $7.3 \mathrm{~Hz})$ (aromatic protons) ppm. ${ }^{13} \mathrm{C}-\mathrm{NMR}\left(\mathrm{CDCl}_{3}\right) \delta: 42.50(\mathrm{t}), 43.56(\mathrm{t}), 44.23(\mathrm{t}), 96.13(\mathrm{~d})$, 108.51 (d), 119.93 (d), 119.98 (d), 120.57 (d), 127.90 (s), 134.55 (s), 136.24 (s) ppm. 
2a oxalate salt. $\mathrm{Mp} 199-200{ }^{\circ} \mathrm{C} .{ }^{1} \mathrm{H}-\mathrm{NMR}\left(\mathrm{D}_{2} \mathrm{O}, \delta\right): 3.74\left(\mathrm{t}, 2 \mathrm{H}, J=6.0 \mathrm{~Hz}, \mathrm{CH}_{2} \mathrm{CH}_{2} \mathrm{NH}\right) ; 4.30$ (t, $\left.2 \mathrm{H}, J=6.0 \mathrm{~Hz}, \mathrm{CH}_{2} \mathrm{CH}_{2} \mathrm{NH}\right) ; 4.55\left(\mathrm{~s}, 2 \mathrm{H}, \mathrm{CCH}_{2} \mathrm{NH}\right) ; 6.52(\mathrm{~s}, 1 \mathrm{H}), 7.19(\mathrm{dd}, 1 \mathrm{H}, J=7.3 \mathrm{~Hz}$ and $7.0 \mathrm{~Hz}), 7.29(\mathrm{dd}, 1 \mathrm{H}, J=8.1 \mathrm{~Hz}$ and $7.0 \mathrm{~Hz}), 7.44(\mathrm{~d}, 1 \mathrm{H}, J=8.1 \mathrm{~Hz}), 7.64(\mathrm{~d}, 1 \mathrm{H}, J=7.3$ $\mathrm{Hz}$ ) (aromatic protons) ppm. ${ }^{13} \mathrm{C}-\mathrm{NMR}\left(\mathrm{D}_{2} \mathrm{O}, \delta\right): 38.50(\mathrm{t}), 41.33(\mathrm{t}), 41.33(\mathrm{t}), 97.12(\mathrm{~d}), 109.36$ (d), 120.39 (d), 120.56 (d), 121.96 (d), 127.26 (s), 127.26 (s), 136.11 (s), 165.06 (s) ppm.

2-Methyl-1,2,3,4-tetrahydro-pyrazino[1,2-a]indole (2b). ${ }^{28}$ Method A: a mixture of $2 \mathrm{a}(0.1 \mathrm{~g}$, $0.58 \mathrm{mmol}),\left(\mathrm{CH}_{2} \mathrm{O}\right)_{\mathrm{n}}(0.15 \mathrm{~g}, 5.14 \mathrm{mmol})$ and $\mathrm{Pd} / \mathrm{C} 10 \%(0.02 \mathrm{~g})$ in absolute ethanol $(20 \mathrm{~mL})$ was hydrogenated at $40 \mathrm{psi}$ at room temperature for 2 days. The catalyst was filtered off and the solvent removed to give a residue that was purified by column chromatography $\left(\mathrm{CHCl}_{3} /\right.$ petroleum ether/Et $\left.2 \mathrm{O} / \mathrm{EtOH} / \mathrm{NH}_{3} 360 / 900 / 360 / 180 / 9.9\right)$ obtaining $0.01 \mathrm{~g}$ of $2 \mathrm{a}$ and $0.01 \mathrm{~g}$ of $\mathbf{2} \mathbf{b}$ ( $9 \%$ yield).

Method B: a solution of 2a $(0.06 \mathrm{~g}, 0.35 \mathrm{mmol})$ and $\mathrm{CH}_{3} \mathrm{I}(0.06 \mathrm{~mL}, 1.05 \mathrm{mmol})$ in anhydrous DMF $(10 \mathrm{~mL})$ was stirred at room temperature in the dark for 2 days. The solvent and the excess of reagent were distilled off and the residue treated with water and extracted with $\mathrm{CH}_{2} \mathrm{Cl}_{2}$. Drying $\left(\mathrm{Na}_{2} \mathrm{SO}_{4}\right)$ and removal of the solvent gave $0.02 \mathrm{~g}$ (31\% yield) of the title compound.

Method $C$ : 2a $(0.15 \mathrm{~g}, 0.87 \mathrm{mmol})$ was dissolved in $4.4 \mathrm{~mL}$ of a $4: 1$ mixture of $\mathrm{Na}_{2} \mathrm{CO}_{3} 2 \mathrm{M} / 1,4-$ dioxane and the solution kept at $0^{\circ} \mathrm{C}$. A solution of ClCOOBz $(0.3 \mathrm{~mL}, 2.13 \mathrm{mmol})$ in $1.8 \mathrm{~mL}$ of 1,4-dioxane and a solution of $\mathrm{NaOH} 2 \mathrm{M}(1.1 \mathrm{~mL}, 2.2 \mathrm{mmol})$ were then added dropwise simultaneously. After $3.5 \mathrm{~h}$ of stirring, the organic solvent was distilled off and the mixture extracted with $\mathrm{CH}_{2} \mathrm{Cl}_{2}$. Drying $\left(\mathrm{Na}_{2} \mathrm{SO}_{4}\right)$ and removal of the solvent gave $0.26 \mathrm{~g}$ of benzyl 3,4Dihydro-1H-pyrazino[1,2-a]indole-2-carboxylate (7) (white solid, 97\% yield). Mp 78-79 ${ }^{\circ} \mathrm{C}$. ${ }^{1} \mathrm{H}-\mathrm{NMR}\left(\mathrm{CDCl}_{3}, \delta\right): 4.02-4.12\left(\mathrm{~m}, 4 \mathrm{H}, \mathrm{NCH}_{2} \mathrm{CH}_{2} \mathrm{~N}\right) ; 4.92\left(\mathrm{~s}, 2 \mathrm{H}, \mathrm{CCH}_{2} \mathrm{~N}\right) ; 5.22(\mathrm{~s}, 2 \mathrm{H}$, $\left.\mathrm{OCH}_{2} \mathrm{Bz}\right) ; 6.31(\mathrm{~s}, 1 \mathrm{H}), 7.10-7.40(\mathrm{~m}, 8 \mathrm{H}), 7.59(\mathrm{~d}, 1 \mathrm{H}, J=7.3 \mathrm{~Hz})$ (aromatic protons) ppm. Compound $7(0.26 \mathrm{~g}, 1.01 \mathrm{mmol})$ was dissolved in $4 \mathrm{~mL}$ of anhydrous DME and the solution added dropwise to a suspension of $\mathrm{LiAlH}_{4}(0.24 \mathrm{~g}, 6.43 \mathrm{mmol})$ in $2 \mathrm{~mL}$ of anhydrous DME at $18{ }^{\circ} \mathrm{C}$. The mixture was allowed to reach room temperature and after $1.5 \mathrm{~h}$ the excess of hydride was destroyed with ice. DME was evaporated, the residue dissolved in $\mathrm{HCl} 0.1 \mathrm{~N}$ and washed with $\mathrm{CH}_{2} \mathrm{Cl}_{2}$. The aqueous phase was then alkalinized with $\mathrm{NaOH}$ and extracted with $\mathrm{CH}_{2} \mathrm{Cl}_{2}$. Drying $\left(\mathrm{Na}_{2} \mathrm{SO}_{4}\right)$ and removal of the solvent gave a solid that was purified by flash chromatography $\left(\mathrm{CHCl}_{3} /\right.$ petroleum ether/Et $\left.2 \mathrm{O} / \mathrm{EtOH} / \mathrm{NH}_{3} 360 / 900 / 360 / 180 / 9.9\right)$ to give $0.16 \mathrm{~g}$ of $\mathbf{2 b}$ (white crystals, 85\% yield). Mp 123-125 ${ }^{\circ} \mathrm{C}$ (lit. $\left.{ }^{28} 130-133\right) .{ }^{1} \mathrm{H}-\mathrm{NMR}\left(\mathrm{CDCl}_{3}, \delta\right): 2.54$ (s, $\left.3 \mathrm{H}, \mathrm{NCH}_{3}\right) ; 2.94\left(\mathrm{t}, 2 \mathrm{H}, J=5.7 \mathrm{~Hz}, \mathrm{NCH}_{2} \mathrm{CH}_{2} \mathrm{NCH}_{3}\right) ; 3.81\left(\mathrm{~s}, 2 \mathrm{H}, \mathrm{CCH}_{2} \mathrm{~N}\right) ; 4.15(\mathrm{t}, J=5.7 \mathrm{~Hz}$, $\left.\mathrm{NCH}_{2} \mathrm{CH}_{2} \mathrm{NCH}_{3}\right) ; 6.26(\mathrm{~s}, 1 \mathrm{H}), 7.12-7.33(\mathrm{~m}, 3 \mathrm{H}), 7.61(\mathrm{~d}, 1 \mathrm{H}, J=7.0 \mathrm{~Hz})$ (aromatic protons) ppm. ${ }^{13} \mathrm{C}-\mathrm{NMR}\left(\mathrm{CDCl}_{3}, \delta\right): 41.91(\mathrm{t}), 45.98(\mathrm{q}), 52.58$ (t), 53.61 (t), 96.41 (d), 108.67 (d), 119.81 (d), 120.08 (d), 120.57 (d), 128.35 (s), 134.37 (s), 136.01 (s) ppm.

2b oxalate salt. Mp 167-169 ${ }^{\circ} \mathrm{C} .{ }^{1} \mathrm{H}-\mathrm{NMR}\left(\mathrm{D}_{2} \mathrm{O}, \delta\right): 2.96\left(\mathrm{~s}, 3 \mathrm{H}, \mathrm{NCH}_{3}\right) ; 3.32-3.49(\mathrm{~m}, 1 \mathrm{H}$, $\left.\mathrm{NCH}_{2} \mathrm{CH}_{2} \mathrm{~N}\right) ; 3.76-3.82\left(\mathrm{~m}, 1 \mathrm{H}, \mathrm{NCH}_{2} \mathrm{CH}_{2} \mathrm{~N}\right) ; 3.98-4.32\left(\mathrm{~m}, 2 \mathrm{H}, \mathrm{NCH}_{2} \mathrm{CH}_{2} \mathrm{~N}\right) ; 4.17(\mathrm{~d}, 1 \mathrm{H}, J=$ $\left.15.2 \mathrm{~Hz}, \mathrm{CCH}_{2} \mathrm{NHCH}_{3}\right) ; 4.61\left(\mathrm{~d}, 1 \mathrm{H}, J=15.2 \mathrm{~Hz}, \mathrm{CCH}_{2} \mathrm{NHCH}_{3}\right) ; 6.42(\mathrm{~s}, 1 \mathrm{H}), 7.11-7.37$ (m, $3 \mathrm{H}), 7.60(\mathrm{~d}, 1 \mathrm{H}, J=7.3 \mathrm{~Hz})$ (aromatic protons) ppm. ${ }^{13} \mathrm{C}-\mathrm{NMR}\left(\mathrm{D}_{2} \mathrm{O}, \delta\right): 38.27(\mathrm{t}), 41.82(\mathrm{q})$, 50.53 (t), 50.84 (t), 99.67, 109.49 (d), 120.50 (d), 120.67 (d), 122.18 (d), 126.79 (s), 127.30 (s), 136.07 (s), 164.93 (s) ppm.

2-Methyl-1,2,3,4,10,10a-hexahydropyrazino[1,2-a]indole (4b). $\mathrm{NaCNBH}_{3}(0.19 \mathrm{~g}, 2.96 \mathrm{mmol})$ was added to a solution of $2 \mathbf{b}(0.11 \mathrm{~g}, 0.59 \mathrm{mmol})$ in $3 \mathrm{~mL}$ of $\mathrm{CH}_{3} \mathrm{COOH}$ at $0^{\circ} \mathrm{C}$ and the mixture 
was allowed to reach room temperature. After $3.5 \mathrm{~h}$ the reaction was quenched with ice. $\mathrm{NaOH}$ $10 \%(30 \mathrm{~mL})$ was added and the mixture extracted with $\mathrm{CH}_{2} \mathrm{Cl}_{2}$. The organic phase was then washed with water, anhydrified and evaporated to give an oily residue. Purification by flash chromatography $\left(\mathrm{CHCl}_{3} /\right.$ petroleum ether/Et $\left.{ }_{2} \mathrm{O} / \mathrm{EtOH} / \mathrm{NH}_{3} 360 / 900 / 360 / 180 / 9.9\right)$ yielded $0.11 \mathrm{~g}$ (yellow oil, 99\%) of the title compound. ${ }^{1} \mathrm{H}-\mathrm{NMR}\left(\mathrm{CDCl}_{3}, \delta\right): 2.08(\mathrm{t}, 1 \mathrm{H}, J=10.6 \mathrm{~Hz}) ; 2.17$ (td, $1 \mathrm{H}, J=11.7 \mathrm{~Hz}$ and $3.3 \mathrm{~Hz}) ; 2.33\left(\mathrm{~s}, 3 \mathrm{H}, \mathrm{NCH}_{3}\right) ; 2.58(\mathrm{dd}, 1 \mathrm{H}, J=15.0 \mathrm{~Hz}$ and $8.1 \mathrm{~Hz}) ; 2.73-$ $2.86(\mathrm{~m}, 2 \mathrm{H}) ; 2.95-3.14(\mathrm{~m}, 2 \mathrm{H}) ; 3.54-3.70(\mathrm{~m}, 2 \mathrm{H}) ; 6.45(\mathrm{~d}, 1 \mathrm{H}, J=8.1 \mathrm{~Hz}), 6.62-6.69(\mathrm{~m}, 1 \mathrm{H})$, 7.04-7.11 (m, 2H) (aromatic protons) ppm. ${ }^{13} \mathrm{C}-\mathrm{NMR}\left(\mathrm{CDCl}_{3}, \delta\right): 32.94(\mathrm{t}), 44.11(\mathrm{t}), 46.51(\mathrm{q})$, 53.50 (t), 58.98 (t), 62.41 (d), 106.24 (d), 117.69 (d), 124.85 (d), 127.45 (d), 129.31 (s), 150.58 (s) ppm. Anal. Calcd for $\mathrm{C}_{12} \mathrm{H}_{16} \mathrm{~N}_{2}$ : C, 76.55; H, 8.57; N, 14.88. Found C, 76.35; H, 8.48; N, 14.58.

4b oxalate salt. Mp 97-99 ${ }^{\circ} \mathrm{C} .{ }^{1} \mathrm{H}-\mathrm{NMR}\left(\mathrm{D}_{2} \mathrm{O}, \delta\right): 2.56-3.41(\mathrm{~m}, 7 \mathrm{H}) ; 2.76\left(\mathrm{~s}, 3 \mathrm{H}, \mathrm{NCH}_{3}\right) ; 3.74-$ $3.90(\mathrm{~m}, 2 \mathrm{H}) ; 6.67(\mathrm{~d}, 1 \mathrm{H}, J=7.7 \mathrm{~Hz}), 6.77-6.85(\mathrm{~m}, 1 \mathrm{H}), 7.10-7.19(\mathrm{~m}, 2 \mathrm{H})$ (aromatic protons) ppm. ${ }^{13} \mathrm{C}-\mathrm{NMR}\left(\mathrm{D}_{2} \mathrm{O}, \delta\right): 31.55(\mathrm{t}), 41.07(\mathrm{t}), 43.28(\mathrm{q}), 50.73(\mathrm{t}), 54.08(\mathrm{t}), 58.85(\mathrm{~d}), 108.60(\mathrm{~d})$, 120.27 (d), 125.51 (d), 127.75 (d), 128.90 (s), 147.56 (s), 164.04 (s) ppm.

1,2,3,4,10,10a-Hexahydropyrazino[1,2-a]indole (4a). ${ }^{30}$ Following the procedure used for $\mathbf{4 b}$, starting from $0.27 \mathrm{~g}(1.57 \mathrm{mmol})$ of $2 \mathrm{a}$ and $0.49 \mathrm{~g}(7.85 \mathrm{mmol})$ of $\mathrm{NaCNBH}_{3}$, the desired product was obtained in $73 \%$ yield $(0.2 \mathrm{~g})$ as an oil. ${ }^{1} \mathrm{H}-\mathrm{NMR}\left(\mathrm{CDCl}_{3}, \delta\right): 1.83(\mathrm{bs}, 1 \mathrm{H}, \mathrm{NH}) ; 2.56(\mathrm{dd}$, $1 \mathrm{H}, J=15.0 \mathrm{~Hz}$ and $9.5 \mathrm{~Hz}) ; 2.73-3.13(\mathrm{~m}, 6 \mathrm{H}) ; 3.33-3.62(\mathrm{~m}, 2 \mathrm{H}) ; 6.45(\mathrm{~d}, 1 \mathrm{H}, J=8.1 \mathrm{~Hz})$, $6.66(\mathrm{~m}, 1 \mathrm{H}), 7.05-7.12(\mathrm{~m}, 2 \mathrm{H})$ (aromatic protons) ppm. ${ }^{13} \mathrm{C}-\mathrm{NMR}\left(\mathrm{CDCl}_{3}, \delta\right): 32.95(\mathrm{t}), 44.68$ (t), $45.66(\mathrm{t}), 50.25$ (t), 64.09 (d), 105.84 (d), 117.73 (d), 124.72 (d), 127.38 (d), 128.91 (s), 151.07 (s) ppm.

4a oxalate salt. Mp 169-173 ${ }^{\circ} \mathrm{C}$ (with decomposition). ${ }^{1} \mathrm{H}-\mathrm{NMR}\left(\mathrm{D}_{2} \mathrm{O}, \delta\right): 2.56(\mathrm{dd}, 1 \mathrm{H}, J=$ $15.7 \mathrm{~Hz}$ and $5.9 \mathrm{~Hz}) ; 2.80-3.28(\mathrm{~m}, 6 \mathrm{H}) ; 3.61-3.80(\mathrm{~m}, 2 \mathrm{H}) ; 6.62(\mathrm{~d}, 1 \mathrm{H}, J=8.1 \mathrm{~Hz}), 6.74(\mathrm{~m}$, 1H), 7.04-7.14 (m, 2H) (aromatic protons) ppm. ${ }^{13} \mathrm{C}-\mathrm{NMR}$ (DMSO, $\delta$ ): 31.97, 40.91, 41.31, 45.30, 58.97, 106.83, 118.39, 124.76, 127.38, 127.98, 149.51, 164.57 ppm.

2,2-Dimethyl-1,2,3,4-tetrahydropyrazino[1,2-a]indol-2-ium iodide (2c). To a solution of $\mathbf{2 b}$ $(0.07 \mathrm{~g}, 0.27 \mathrm{mmol})$ in $5 \mathrm{~mL}$ of $\mathrm{Et}_{2} \mathrm{O} \mathrm{MeI}(0.2 \mathrm{~mL}, 3.21 \mathrm{mmol})$ was added and the solution stirred for $48 \mathrm{~h}$ in the dark. The mixture was then filtered and the solid residue dried to give $0.08 \mathrm{~g}$ of the title compound in $91 \%$ yield (white solid). $\mathrm{Mp}>250{ }^{\circ} \mathrm{C}$. ${ }^{1} \mathrm{H}-\mathrm{NMR}$ (DMSO, $\delta$ ): 3.26 $\left(\mathrm{s}, 6 \mathrm{H}, \mathrm{N}\left(\mathrm{CH}_{3}\right)_{2}\right) ; 4.09$ (t, 2H, $\left.J=5.5 \mathrm{~Hz}, \mathrm{CH}_{2} \mathrm{~N}\right) ; 4.46\left(\mathrm{t}, 2 \mathrm{H}, J=5.5 \mathrm{~Hz}, \mathrm{CH}_{2} \mathrm{~N}\right) ; 4.92$ (s, 2H, $\left.\mathrm{CH}_{2} \mathrm{~N}\right) ; 6.53(\mathrm{~s}, 1 \mathrm{H}), 7.08-7.27(\mathrm{~m}, 2 \mathrm{H}), 7.49-7.61(\mathrm{~m}, 2 \mathrm{H})$ (aromatic protons) ppm. ${ }^{13} \mathrm{C}-\mathrm{NMR}$ (DMSO, 8): 37.40 (t), 50.50 (q), 57.73 (t), 58.87 (t), 100.72 (d), 110.08 (d), 120.38 (d), 120.49 (d), 121.95 (d), 126.72 (s), 127.48 (s), 136.33 (s) ppm. Anal. Calcd. for $\mathrm{C}_{13} \mathrm{H}_{17} \mathrm{~N}_{2} \mathrm{I}$ : C, 47.58; $\mathrm{H}$, 5.22; N, 8.54. Found: C, 47.21; H, 5.27; N, 8.23.

2,2-Dimethyl-1,2,3,4,10,10a-hexahydropyrazino[1,2-a]indol-2-ium iodide (4c). Following the procedure used for 2c, starting from $0.07 \mathrm{~g}(0.37 \mathrm{mmol})$ of $\mathbf{4 b}$ and $0.2 \mathrm{~mL}(3.21 \mathrm{mmol})$ of MeI, the desired product was obtained in $49 \%$ yield $(0.06 \mathrm{~g})$ as a white solid. Mp $184-186{ }^{\circ} \mathrm{C}$ with decomposition. ${ }^{1} \mathrm{H}-\mathrm{NMR}\left(\mathrm{D}_{2} \mathrm{O}, \delta\right): 2.67(\mathrm{dd}, 1 \mathrm{H}, J=16.1 \mathrm{~Hz}$ and $2.9 \mathrm{~Hz}, \mathrm{CH}) ; 3.08-3.47$ (m, $11 \mathrm{H}) ; 3.08\left(\mathrm{~s}, 3 \mathrm{H}, \mathrm{CH}_{3} \mathrm{~N}\right) ; 3.23\left(\mathrm{~s}, 3 \mathrm{H}, \mathrm{CH}_{3} \mathrm{~N}\right) ; 3.63(\mathrm{td}, 1 \mathrm{H}, J=12.1 \mathrm{~Hz}$ and $3.3 \mathrm{~Hz}, \mathrm{CH}) ; 3.85-$ $3.93(\mathrm{~m}, 1 \mathrm{H}, \mathrm{CH}) ; 4.14-4.24(\mathrm{~m}, 1 \mathrm{H}, \mathrm{CH}) ; 6.76(\mathrm{~d}, 1 \mathrm{H}, J=7.7 \mathrm{~Hz}), 6.88(\mathrm{dd}, 1 \mathrm{H}, J=7.7 \mathrm{~Hz}$ and $7.3 \mathrm{~Hz}), 7.17-7.26(\mathrm{~m}, 2 \mathrm{H})$ (aromatic protons) ppm. ${ }^{13} \mathrm{C}-\mathrm{NMR}\left(\mathrm{D}_{2} \mathrm{O}, \delta\right): 31.52(\mathrm{t}), 38.13(\mathrm{t})$, 46.70 (q), 55.19 (d), 56.61 (q), 58.12 (t), 61.16 (t), 108.83 (d), 120.34 (d), 125.69 (d), 127.88 (d), 
128.72 (s), 147.40 (s) ppm. Anal. Calcd. for $\mathrm{C}_{13} \mathrm{H}_{19} \mathrm{~N}_{2} \mathrm{I}$ : C, 47.29; H, 5.80; N, 8.48. Found: C, 46.97; H, 5.70; N, 8.51.

Ethyl 3-(3-nitropyridin-4-yl)-2-oxo-propanoate (8). ${ }^{31}$ Diethyl oxalate $(2.25 \mathrm{~mL}, 16.57 \mathrm{mmol})$ was added dropwise to a stirred solution of NaOEt ( $16.05 \mathrm{mmol}$, from $0.37 \mathrm{~g}$ of Na) in $20 \mathrm{~mL}$ of anhydrous EtOH; then, 4-methyl-3-nitro-pyridine (2 $\mathrm{g}, 14.48 \mathrm{mmol})$ dissolved in $30 \mathrm{~mL}$ of anhydrous toluene was added causing the formation of a deep red color. The solution was stirred at room temperature for $2.5 \mathrm{~h}$, then the solvents were evaporated, the residue dissolved in water and treated with $\mathrm{AcOH}$ to form a red precipitate that was extracted with EtOAc. Drying and evaporation of the solvent gave a mixture that was purified by flash chromatography (toluene/EtOAc, $8 / 2$ as first eluent and $5 / 5$ as second eluent) to give $1.45 \mathrm{~g}$ of $\mathbf{8}$ (red solid, yield $42 \%$ ). Mp 117-119 ${ }^{\circ} \mathrm{C} .{ }^{1} \mathrm{H}-\mathrm{NMR}\left(\mathrm{CDCl}_{3}, \delta\right)$ (as 2:1 mixture of keto and enol ester tautomers): 1.42 (t, $\left.6 \mathrm{H}, J=7.1 \mathrm{~Hz}, \mathrm{CH}_{2} \mathrm{CH}_{3}\right)$; 4.36-4.49 (m, $\left.4 \mathrm{H}, J=7.1 \mathrm{~Hz}, \mathrm{CH}_{2} \mathrm{CH}_{3}\right) ; 4.59$ (bs, $1 \mathrm{H}, \mathrm{OH}$ of enol form); $4.61\left(\mathrm{~s}, 2 \mathrm{H}, \mathrm{CH}_{2} \mathrm{CO}\right) ; 6.99(\mathrm{~s}, 1 \mathrm{H}, \mathrm{CH}=\mathrm{C}) ; 7.32(\mathrm{~d}, 1 \mathrm{H}, J=5.1 \mathrm{~Hz}), 8.83(\mathrm{~d}, 1 \mathrm{H}, J=$ $5.1 \mathrm{~Hz}), 9.38(\mathrm{~s}, 1 \mathrm{H})$ (aromatic protons of keto form); $8.23(\mathrm{~d}, 1 \mathrm{H}, J=5.5 \mathrm{~Hz}), 8.78(\mathrm{~d}, 1 \mathrm{H}, J=$ $5.5 \mathrm{~Hz}$ ), $9.15(\mathrm{~s}, 1 \mathrm{H})$ (aromatic protons of enol form) ppm.

Ethyl 1,2-dihydroxy-2,3-dihydro-1H-pyrrolo[2,3-c]pyridine-2-carboxylate (9). A suspension of $8(1.82 \mathrm{~g}, 7.65 \mathrm{mmol})$ in $120 \mathrm{~mL}$ of $\mathrm{CH}_{2} \mathrm{Cl}_{2}$ was hydrogenated at $30 \mathrm{psi}$ at room temperature with $\mathrm{Pd} / \mathrm{C} 10 \%(0.23 \mathrm{~g})$ for $48 \mathrm{~h}$. The solid was filtered off and washed several times with boiling EtOH. Removal of the solvents gave $1.31 \mathrm{~g}$ of the title compound in $76 \%$ yield (pale brown crystals). Mp 138-140 ${ }^{\circ} \mathrm{C}$ (with decomposition). ${ }^{1} \mathrm{H}-\mathrm{NMR}$ (DMSO, $\delta$ ): 1.17 (t, 3H, $J=$ $\left.7.1 \mathrm{~Hz}, \mathrm{CH}_{2} \mathrm{CH}_{3}\right) ; 3.00$ (d, $1 \mathrm{H}, J=16.7 \mathrm{~Hz}$, benzylic proton); 3.34 (d, $1 \mathrm{H}, J=16.7 \mathrm{~Hz}$, benzylic proton); 4.13 (q, $\left.2 \mathrm{H}, J=7.1 \mathrm{~Hz}, \mathrm{CH}_{2} \mathrm{CH}_{3}\right) ; 6.69(\mathrm{~s}, 1 \mathrm{H}, \mathrm{OH}) ; 7.15(\mathrm{~d}, 1 \mathrm{H}, J=4.8 \mathrm{~Hz}), 7.95$ (s, $1 \mathrm{H}), 8.08\left(\mathrm{~d}, 1 \mathrm{H}, J=4.8 \mathrm{~Hz}\right.$ ) (aromatic protons); $9.43(\mathrm{~s}, 1 \mathrm{H}, \mathrm{OH}) \mathrm{ppm} .{ }^{13} \mathrm{C}-\mathrm{NMR}(\mathrm{DMSO}, \delta)$ : 14.37 (q), 39.67 (t), 61.66 (t), 97.02 (s), 120.13 (d), 132.26 (d), 134.90 (s), 142.93 (d), 147.81 (s), 170.11 (s) ppm. MS: $224\left(M^{+}\right)$. IR (nujol) $v 3239(\mathrm{OH}), 1740(\mathrm{C}=\mathrm{O}) \mathrm{cm}^{-1}$. Anal. Calcd. for $\mathrm{C}_{10} \mathrm{H}_{12} \mathrm{~N}_{2} \mathrm{O}_{4}$ : C, 53.57; H, 5.39; N, 12.49. Found: C, 53.82; H, 5.45; N, 12.78.

Ethyl 1H-pyrrolo[2,3-c]pyridine-2-carboxylate (10). ${ }^{31}$ Method $A$ : a suspension of 8 (1.45 g, $6.09 \mathrm{mmol}$ ) in $200 \mathrm{~mL}$ of $\mathrm{CH}_{2} \mathrm{Cl}_{2}$ was hydrogenated at $35 \mathrm{psi}$ at room temperature with $\mathrm{Pd} / \mathrm{C}$ $10 \%(0.18 \mathrm{~g})$ for $72 \mathrm{~h}$. The solid was filtered off and washed several times with $\mathrm{CH}_{2} \mathrm{Cl}_{2} / \mathrm{EtOH}$ $1 / 1$. Removal of the solvents gave $0.97 \mathrm{~g}$ of the title compound in $84 \%$ yield.

Method B: a suspension of $9(0.68 \mathrm{~g}, 3.04 \mathrm{mmol})$ in $40 \mathrm{~mL}$ of abs. EtOH was hydrogenated at $110 \mathrm{psi}$ at room temperature with $\mathrm{Pd} / \mathrm{C} 10 \%(0.3 \mathrm{~g})$ for $36 \mathrm{~h}$. The solid was filtered off and washed several times with $\mathrm{CH}_{2} \mathrm{Cl}_{2} / \mathrm{EtOH} \mathrm{1/1}$. Removal of the solvents gave $0.54 \mathrm{~g}$ of the title compound in $93.5 \%$ yield (white crystals). Mp 207-208 ${ }^{\circ} \mathrm{C} .{ }^{1} \mathrm{H}-\mathrm{NMR}\left(\mathrm{CDCl}_{3}, \delta\right): 1.45(\mathrm{t}, 3 \mathrm{H}, J=$ $\left.7.2 \mathrm{~Hz}, \mathrm{CH}_{2} \mathrm{CH}_{3}\right) ; 4.47$ (q, $\left.2 \mathrm{H}, J=7.2 \mathrm{~Hz}, \mathrm{CH}_{2} \mathrm{CH}_{3}\right) ; 7.22(\mathrm{~s}, 1 \mathrm{H}), 7.61(\mathrm{~d}, 1 \mathrm{H}, J=5.5 \mathrm{~Hz}), 8.35$ $(\mathrm{d}, 1 \mathrm{H}, J=5.5 \mathrm{~Hz}), 8.97(\mathrm{~s}, 1 \mathrm{H})$ (aromatic protons) ppm. ${ }^{13} \mathrm{C}-\mathrm{NMR}$ (DMSO, $\left.\delta\right): 14.24(\mathrm{q}), 61.04$ (t), 106.22 (d), 116.01 (d), 130.47 (s), 130.62 (s), 133.91 (s), 136.37 (d), 138.30 (d), 160.86 (s) ppm.

Ethyl 1-cyanomethyl-1H-pyrrolo[2,3-c]pyridine-2-carboxylate (11). To a solution of 10 $(0.15 \mathrm{~g}, 0.79 \mathrm{mmol})$ in anhydrous DMF $(4 \mathrm{~mL})$ potassium tert-butoxide $(0.13 \mathrm{~g}, 1.18 \mathrm{mmol})$ was added at room temperature. After $40 \mathrm{~min}$, chloroacetonitrile $(0.07 \mathrm{~mL}, 1.18 \mathrm{mmol})$ was added dropwise and the solution heated at $65^{\circ} \mathrm{C}$ for $30 \mathrm{~min}$ and left stirring at room temperature for $20 \mathrm{~h}$. Water $(20 \mathrm{~mL})$ was then added and all the solvents distilled off to give a solid residue that 
was treated with water and extracted with $\mathrm{CH}_{2} \mathrm{Cl}_{2}$. Drying $\left(\mathrm{Na}_{2} \mathrm{SO}_{4}\right)$ and removal of the solvent gave $0.18 \mathrm{~g}$ of the title compound (yellow solid, $84 \%$ yield). $\mathrm{Mp} 78-79{ }^{\circ} \mathrm{C} .{ }^{1} \mathrm{H}-\mathrm{NMR}\left(\mathrm{CDCl}_{3}, \delta\right)$ : $1.45\left(\mathrm{t}, 3 \mathrm{H}, J=7.1 \mathrm{~Hz}, \mathrm{CH}_{2} \mathrm{CH}_{3}\right) ; 4.47\left(\mathrm{q}, 2 \mathrm{H}, J=7.1 \mathrm{~Hz}, \mathrm{CH}_{2} \mathrm{CH}_{3}\right) ; 5.69\left(\mathrm{~s}, 2 \mathrm{H}, \mathrm{CH}_{2} \mathrm{CN}\right) ; 7.37$ $(\mathrm{s}, 1 \mathrm{H}), 7.61(\mathrm{~d}, 1 \mathrm{H}, J=5.5 \mathrm{~Hz}), 8.44(\mathrm{~d}, 1 \mathrm{H}, J=5.5 \mathrm{~Hz}), 8.98(\mathrm{~s}, 1 \mathrm{H})$ (aromatic protons) ppm. ${ }^{13} \mathrm{C}-\mathrm{NMR}-\mathrm{APT}\left(\mathrm{CDCl}_{3}, \delta\right): 14.24,32.76,61.93,110.93,114.54,116.65,129.54,131.02,133.60$, 134.86, 140.58, 161.15 ppm. Anal. Calcd. for $\mathrm{C}_{12} \mathrm{H}_{11} \mathrm{~N}_{3} \mathrm{O}_{2}$ : C, 62.87; H, 4.84; N, 18.33. Found: C, 62.95; H, 5.03; N, 18.11.

3,4-Dihydropyrido[4',3':4,5]pyrrolo[1,2-a]pyrazin-1(2H)-one (13). Compound 11 (0.33 g, $1.44 \mathrm{mmol}$ ), dissolved in $30 \mathrm{~mL}$ of $\mathrm{THF} / \mathrm{CH}_{3} \mathrm{OH} 1 / 1$ was hydrogenated at 105 psi at room temperature with Ni-Raney $\left(50 \%\right.$ in $\left.\mathrm{H}_{2} \mathrm{O}, 2 \mathrm{~g}\right)$ for $72 \mathrm{~h}$. The solid was filtered off and washed with $\mathrm{CH}_{3} \mathrm{OH}$, the solvents were evaporated and the residue separated by column chromatography $\left(\mathrm{CH}_{2} \mathrm{Cl}_{2} /\right.$ petroleum ether/EtOH/ $\left.\mathrm{NH}_{3} 340 / 60 / 65 / 8\right)$ to give $0.04 \mathrm{~g}$ of unreacted 11 and $0.1 \mathrm{~g}$ of 13 (yellow solid, 37\% yield). Mp $248{ }^{\circ} \mathrm{C}$ (with decomposition). ${ }^{1} \mathrm{H}-\mathrm{NMR}$ (DMSO, $\delta$ ): $3.65-3.70$ (m, $\left.2 \mathrm{H}, \mathrm{NCH}_{2} \mathrm{CH}_{2} \mathrm{NH}\right) ; 4.38-4.44\left(\mathrm{~m}, 2 \mathrm{H}, \mathrm{NCH}_{2} \mathrm{CH}_{2} \mathrm{NH}\right) ; 7.06(\mathrm{~s}, 1 \mathrm{H}), 7.63(\mathrm{~d}, 1 \mathrm{H}, J=5.5 \mathrm{~Hz})$, $8.19(\mathrm{~d}, 1 \mathrm{H}, J=5.5 \mathrm{~Hz})$ (aromatic protons); $8.38(\mathrm{bs}, 1 \mathrm{H}, \mathrm{NH}) ; 8.98(\mathrm{~s}, 1 \mathrm{H}$, aromatic proton) ppm. ${ }^{13}$ C-NMR (DMSO, \&): 39.40 (t), 40.36 (t), 102.69 (d), 115.76 (d), 130.33 (s), 132.41 (s), 132.83 (s), 134.88 (d), 138.53 (d), 159.47 (s) ppm. Anal. Calcd. for $\mathrm{C}_{10} \mathrm{H}_{9} \mathrm{~N}_{3} \mathrm{O}: \mathrm{C}, 64.16 ; \mathrm{H}$, 4.85; N, 22.45. Found: C, 64.42; H, 5.01; N, 22.28.

1,2,3,4-Tetrahydropyrido[4',3':4,5]pyrrolo[1,2-a]pyrazine (3a). Method $A$ : a solution of 13 $(0.31 \mathrm{~g}, 1.66 \mathrm{mmol})$ in $15 \mathrm{~mL}$ of anhydrous DME was added dropwise to a cooled $\left(0{ }^{\circ} \mathrm{C}\right)$ suspension of $\mathrm{LiAlH}_{4}(0.12 \mathrm{~g}, 3.16 \mathrm{mmol})$ in $10 \mathrm{~mL}$ of the same solvent and the mixture was heated at $80{ }^{\circ} \mathrm{C}$ for $3 \mathrm{~h}$. The excess of hydride was quenched with ice and the solvent was distilled off. Extraction of the residue with $\mathrm{CH}_{2} \mathrm{Cl}_{2} / \mathrm{MeOH} 1: 1$ gave $0.42 \mathrm{~g}$ of mixture that was separated by flash chromatography $\left(\mathrm{CH}_{2} \mathrm{Cl}_{2} / \mathrm{MeOH} 9 / 1\right.$ as first eluent, $\mathrm{CH}_{2} \mathrm{Cl}_{2}$ /petroleum ether/EtOH/ $\mathrm{NH}_{3} 340 / 60 / 65 / 8$ as second eluent) to give $0.1 \mathrm{~g}$ of unreacted 13 and $0.06 \mathrm{~g}$ of 3a (pale red solid, 8\% yield). Mp 144-145 ${ }^{\circ} \mathrm{C}$ (with decomposition). ${ }^{1} \mathrm{H}-\mathrm{NMR}\left(\mathrm{CDCl}_{3}, \delta\right.$ ): 2.01 (bs, $1 \mathrm{H}, \mathrm{NH}) ; 3.36$ (t, 2H, $\left.J=5.7 \mathrm{~Hz}, \mathrm{NCH}_{2} \mathrm{CH}_{2} \mathrm{NH}\right) ; 4.09$ (t, $\left.2 \mathrm{H}, J=5.7 \mathrm{~Hz}, \mathrm{NCH}_{2} \mathrm{CH}_{2} \mathrm{NH}\right) ; 4.23$ (s, $\left.2 \mathrm{H}, \mathrm{CCH}_{2} \mathrm{NH}\right) ; 6.18(\mathrm{~s}, 1 \mathrm{H}), 7.41(\mathrm{~d}, 1 \mathrm{H}, J=5.5 \mathrm{~Hz}), 8.22(\mathrm{~d}, 1 \mathrm{H}, J=5.5 \mathrm{~Hz}), 8.65(\mathrm{~s}, 1 \mathrm{H})$ (aromatic protons) ppm. ${ }^{13} \mathrm{C}-\mathrm{NMR}\left(\mathrm{CDCl}_{3}, \delta\right): 42.83(\mathrm{t}), 43.29(\mathrm{t}), 44.27(\mathrm{t}), 95.86(\mathrm{~d}), 114.49$ (d), 131.62 (d), 132.75 (s), 133.44 (s), 138.61 (s), 139.27 (d) ppm. Anal. Calcd. for $\mathrm{C}_{10} \mathrm{H}_{11} \mathrm{~N}_{3}$ : C, 69.34; H, 6.40; N, 24.26. Found: C, 69.09; H, 6.49; N, 24.38.

3a oxalate salt. $\mathrm{Mp} 82-84{ }^{\circ} \mathrm{C}$ (with decomposition). ${ }^{1} \mathrm{H}-\mathrm{NMR}\left(\mathrm{D}_{2} \mathrm{O}, \delta\right): 3.92(\mathrm{t}, 2 \mathrm{H}, J=5.9 \mathrm{~Hz}$, $\mathrm{NCH}_{2} \mathrm{CH}_{2} \mathrm{NH}$ ); 4.67 (t, $\left.2 \mathrm{H}, J=5.9 \mathrm{~Hz}, \mathrm{NCH}_{2} \mathrm{CH}_{2} \mathrm{NH}\right) ; 4.84$ (s, 2H, $\left.\mathrm{CCH}_{2} \mathrm{NH}\right) ; 6.91$ (s, 1H), $8.04(\mathrm{~d}, 1 \mathrm{H}, J=6.6 \mathrm{~Hz}), 8.19(\mathrm{~d}, 1 \mathrm{H}, J=6.6 \mathrm{~Hz}), 9.03$ (s, 1H) (aromatic protons) ppm.

Method B: $\mathrm{LiAlH}_{4}(0.54 \mathrm{~g}, 14.21 \mathrm{mmol})$ was suspended in $25 \mathrm{~mL}$ of dry DME and a solution of $11(0.98 \mathrm{~g}, 4.28 \mathrm{mmol})$ in $20 \mathrm{~mL}$ of dry DME was added dropwise at room temperature. The mixture was heated at $40{ }^{\circ} \mathrm{C}$ for $2 \mathrm{~h}$, after cooling the excess of hydride was destroyed with ice and the solvent evaporated. The solid residue was extracted with a mixture of $\mathrm{CH}_{2} \mathrm{Cl}_{2} / \mathrm{EtOH} 1 / 1$. Evaporation of the solvents and separation by flash chromatography $\left(\mathrm{CH}_{2} \mathrm{Cl}_{2} /\right.$ petroleum ether/EtOH/ $\left.\mathrm{NH}_{3} 340 / 60 / 65 / 8\right)$ gave $0.1 \mathrm{~g}$ of [1-(2-aminoethyl)-1H-pyrrolo[2,3-c]pyridin-2-yl]methanol (12) (oil, 12\% yield) and $0.06 \mathrm{~g}$ of $3 \mathbf{3 a}$ (10\% yield).

${ }^{1} \mathrm{H}-\mathrm{NMR}(12)\left(\mathrm{CDCl}_{3}, \delta\right): 3.21\left(\mathrm{t}, 2 \mathrm{H}, J=5.0 \mathrm{~Hz}, \mathrm{NCH}_{2} \mathrm{CH}_{2} \mathrm{NH}_{2}\right) ; 4.35$ (t, 2H, $J=5.0 \mathrm{~Hz}$, $\left.\mathrm{NCH}_{2} \mathrm{CH}_{2} \mathrm{NH}_{2}\right) ; 4.76\left(\mathrm{~s}, 2 \mathrm{H}, \mathrm{CH}_{2} \mathrm{OH}\right) ; 6.51(\mathrm{~s}, 1 \mathrm{H}), 7.51(\mathrm{~d}, 1 \mathrm{H}, J=5.5 \mathrm{~Hz}), 8.25(\mathrm{~d}, 1 \mathrm{H}, J=$ 
$5.5 \mathrm{~Hz}), 8.70(\mathrm{~s}, 1 \mathrm{H})$ (aromatic protons) ppm. Anal. Calcd. for $\mathrm{C}_{10} \mathrm{H}_{13} \mathrm{~N}_{3} \mathrm{O}: \mathrm{C}, 62.81 ; \mathrm{H}, 6.85 ; \mathrm{N}$, 21.97. Found: C, 62.98; H, 6.67; N, 22.12.

Benzyl 3,4-dihydropyrido[4',3':4,5]pyrrolo[1,2-a]pyrazine-2(1H)-carboxylate (14). 3a $(0.04 \mathrm{~g}, 0.23 \mathrm{mmol})$ was dissolved in $1.2 \mathrm{~mL}$ of a $4: 1$ mixture of $\mathrm{Na}_{2} \mathrm{CO}_{3} 2 \mathrm{M} / 1$,4-dioxane and the solution kept at $0{ }^{\circ} \mathrm{C}$. A solution of $\mathrm{ClCOOBz}(0.04 \mathrm{~mL}, 0.28 \mathrm{mmol})$ in $0.4 \mathrm{~mL}$ of $1,4-$ dioxane and a solution of $\mathrm{NaOH} 2 \mathrm{M}(0.15 \mathrm{~mL}, 0.30 \mathrm{mmol})$ were then added dropwise simultaneously. After $1.5 \mathrm{~h}$ stirring, the organic solvent was distilled off and the mixture treated with water and extracted with $\mathrm{CH}_{2} \mathrm{Cl}_{2}$. Drying $\left(\mathrm{Na}_{2} \mathrm{SO}_{4}\right)$ and removal of the solvent gave $0.09 \mathrm{~g}$ of crude 14 (oil) that was used in the next reaction without further purification. ${ }^{1} \mathrm{H}-\mathrm{NMR}\left(\mathrm{CDCl}_{3}\right.$,

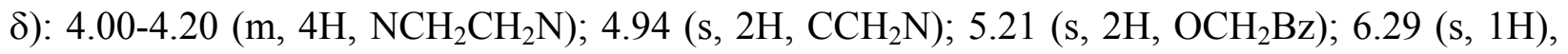
7.28-7.46 (m, 6H), $8.23(\mathrm{~d}, 1 \mathrm{H}, J=5.5 \mathrm{~Hz}), 8.65(\mathrm{~s}, 1 \mathrm{H})$ (aromatic protons) ppm.

2-Methyl-1,2,3,4-tetrahydropyrido[4',3':4,5]pyrrolo[1,2-a]pyrazine (3b). Compound 14 $(0.09 \mathrm{~g}, 0.29 \mathrm{mmol})$ was dissolved in $1.5 \mathrm{~mL}$ of anhydrous DME and the solution added dropwise to a suspension of $\mathrm{LiAlH}_{4}(0.07 \mathrm{~g}, 1.86 \mathrm{mmol})$ in $1 \mathrm{~mL}$ of anhydrous DME at $0{ }^{\circ} \mathrm{C}$. After $30 \mathrm{~min}$, the mixture was allowed to reach room temperature and the excess of hydride was destroyed with ice. DME was evaporated, the residue dissolved in $\mathrm{HCl} 0.1 \mathrm{~N}$ and washed with $\mathrm{CH}_{2} \mathrm{Cl}_{2}$. The aqueous phase was then alkalinized with $\mathrm{NaOH}$ and extracted with $\mathrm{CH}_{2} \mathrm{Cl}_{2}$. Drying $\left(\mathrm{Na}_{2} \mathrm{SO}_{4}\right)$ and removal of the solvent gave a solid that was purified by column chromatography $\left(\mathrm{CH}_{2} \mathrm{Cl}_{2} / \mathrm{MeOH} 9 / 1\right)$ to give $0.03 \mathrm{~g}$ of $3 \mathbf{b}$ (pale brown solid, 55\% yield). $\mathrm{Mp} 121-122{ }^{\circ} \mathrm{C} .{ }^{1} \mathrm{H}-$ NMR $\left(\mathrm{CDCl}_{3}, \delta\right): 2.53\left(\mathrm{~s}, 3 \mathrm{H}, \mathrm{NCH}_{3}\right) ; 2.96\left(\mathrm{t}, 2 \mathrm{H}, J=5.7 \mathrm{~Hz}, \mathrm{NCH}_{2} \mathrm{CH}_{2} \mathrm{NCH}_{3}\right) ; 3.82(\mathrm{~s}, 2 \mathrm{H}$, $\left.\mathrm{CCH}_{2} \mathrm{~N}\right) ; 4.23$ (t, $\left.J=5.7 \mathrm{~Hz}, \mathrm{NCH}_{2} \mathrm{CH}_{2} \mathrm{NCH}_{3}\right) ; 6.21(\mathrm{~s}, 1 \mathrm{H}), 7.44(\mathrm{~d}, 1 \mathrm{H}, J=5.5 \mathrm{~Hz}), 8.23(\mathrm{~d}$, $1 \mathrm{H}, J=5.5 \mathrm{~Hz}), 8.69(\mathrm{~s}, 1 \mathrm{H})$ (aromatic protons) ppm. ${ }^{13} \mathrm{C}-\mathrm{NMR}\left(\mathrm{CDCl}_{3}, \delta\right): 42.21(\mathrm{t}), 45.91(\mathrm{q})$, 52.12 (t), 53.39 (t), 96.09 (d), 114.57 (d), 131.73 (d), 133.15 (s), 138.43 (s), 139.12 (d) ppm. Anal. Calcd. for $\mathrm{C}_{11} \mathrm{H}_{13} \mathrm{~N}_{3}: \mathrm{C}, 70.56 ; \mathrm{H}, 7.00 ; \mathrm{N}, 22.44$. Found C, 70.76; H, 7.13; N, 22.29.

3b oxalate salt. Mp 168-170 ${ }^{\circ} \mathrm{C}$ (with decomposition). ${ }^{13} \mathrm{C}-\mathrm{NMR}-\mathrm{APT}\left(\mathrm{D}_{2} \mathrm{O}, \delta\right): 41.99,45.03$, $52.29,52.91,104.03,119.72,127.81,131.38,133.93,140.37,142.78,167.14$ ppm.

\section{2,2,7-Trimethyl-1,2,3,4-tetrahydropyrido[4',3':4,5]pyrrolo[1,2-a]pyrazine-2,7-diium}

diiodide (15). $\mathrm{MeI}(0.005 \mathrm{~mL}, 0.09 \mathrm{mmol})$ was added to a solution of $3 \mathbf{b}(0.015 \mathrm{~g}, 0.08 \mathrm{mmol})$ in $0.5 \mathrm{~mL}$ of anhydrous DMF and the mixture was kept under stirring at room temperature in the dark for $60 \mathrm{~h}$. Distillation of the solvent gave the title compound as a brown solid (45\% yield). Mp 218-220 ${ }^{\circ} \mathrm{C} .{ }^{1} \mathrm{H}-\mathrm{NMR}\left(\mathrm{D}_{2} \mathrm{O}, \delta\right): 3.38\left(\mathrm{~s}, 6 \mathrm{H}, \mathrm{N}\left(\mathrm{CH}_{3}\right)_{2}\right) ; 4.14-4.20\left(\mathrm{~m}, 2 \mathrm{H}, \mathrm{CH}_{2} \mathrm{~N}\right) ; 4.36(\mathrm{~s}$, $\left.3 \mathrm{H}, \mathrm{CH}_{3} \mathrm{~N}\right)$; 4.75-4.80 (m, 2H, $\left.\mathrm{NCH}_{2}\right) ; 5.08\left(\mathrm{~s}, 2 \mathrm{H}, \mathrm{CH}_{2} \mathrm{~N}\right) ; 6.93(\mathrm{~s}, 1 \mathrm{H}), 8.02(\mathrm{~d}, 1 \mathrm{H}, J=$ $6.6 \mathrm{~Hz}), 8.18(\mathrm{~d}, 1 \mathrm{H}, J=6.6 \mathrm{~Hz}), 9.15(\mathrm{~s}, 1 \mathrm{H})$ (aromatic protons) ppm. Anal. Calcd. for $\mathrm{C}_{13} \mathrm{H}_{19} \mathrm{~N}_{3} \mathrm{I}_{2}$ : C, 33.14; H, 4.06; N, 8.92. Found: C, 32.96; H, 4.18; N, 9.05.

\section{Molecular modeling}

For quantomechanical calculations, the compounds were sketched using Spartan '04 (PC Spartan '04 Windows, V. 1.0.0, Wavefunction, Inc., 18401 Von Karman Ave., Suite 370, Irvine, CA 92612, USA), and minimized to convergence using the quantum mechanical semiempirical program AM1 and the ab initio RHF procedure (basis set 6-31G*) within Spartan '04. The volumes of compounds 2c and 4c (226.35 $\AA^{3}$ and $230.93 \AA^{3}$, respectively) were calculated for the conformations optimized with the $a b$ initio method. Molecular mechanics calculations were performed on a SGI R8000 workstation using the Accelrys programs InsightII and Discover (Version 2000), using the cff91 force-field for minimization, and Sybyl (Version 6.7). The 
crystal structure of DMPP was retrieved from the Cambridge Structural Database (structure code DMPIPZ).

\section{Acknowledgements}

This work has been supported by funds of the Italian Ministry of Education, University and Research (MIUR).

\section{References}

1. Millar, N. S. Biochem. Soc. Trans. 2003, 31 (Part 4), 869.

2. Hogg, R. C.; Raggenbass, M.; Bertrand, D. Rev. Physiol. Biochem. Pharmacol. 2003, 147, 1.

3. Steinlein, O. K. Curr. Drug Target CNS Neurol. Disord. 2002, 1, 443.

4. Rozycka, A.; Trzeciak, W. H. J. Appl. Genet. 2003, 44, 197.

5. Engel, A.; Ohno, K.; Sine, S. M. Muscle Nerve 2003, 27, 4.

6. Decker, M. W.; Meyer, M. D.; Sullivan, J. P. Expert Opin. Investig. Drugs 2001, 10, 1819.

7. Unwin, N.; Toyoshima, C.; Kubalek, E. J. Cell. Biol. 1988, 107, 1123.

8. Unwin, N. J. Struct. Biol. 1998, 121, 181.

9. Unwin, N. Nature 1995, 373, 37.

10. Miyazawa, A.; Fujiyoshi, Y.; Unwin, N. Nature 2003, 423, 949.

11. Brejc, K.; van Dijk, W. J.; Klaassen, R. V.; Schuurmans, M.; van der Oost, J.; Smit, A. B.; Sixma, T. K. Nature 2001, 411, 269.

12. Le Novère, N.; Grutter, T.; Changeux, J.-P. Proc. Natl. Acad. Sci. U.S.A. 2002, 99, 3210.

13. Costa, V.; Nistri, A.; Cavalli, A.; Carloni, P. Br. J. Pharmacol. 2003, 140, 912.

14. Schapira, M.; Abagyan, R.; Totrov, M. BMC Struct. Biol. 2002, $2,1$.

15. Beers, W. H.; Reich, E. Nature 1970, 228, 917.

16. Glennon, R. A.; Herndon, J. L.; Dukat, M. Med.Chem. Res. 1994, 4, 461.

17. Nicolotti, O.; Pellegrini-Calace, M.; Carrieri, A.; Altomare, C.; Centeno, N. B.; Sanz, F.; Carotti, A. J. Comput-Aid. Mol. Des. 2001, 15, 859.

18. Tonder, J. E.; Olesen, P. H.; Hansen, J. B.; Begtrup, M.; Pettersson, I. J. Comput-Aid. Mol. Des. 2001, 15, 247.

19. Nicolotti, O.; Pellegrini-Calace, M.; Altomare, C.; Carotti, A.; Carrieri, A.; Sanz, F. Curr. Med. Chem. 2002, 9, 1.

20. Gohlke, H.; Schwarz, S.; Gündisch, D.; Tilotta, M. C.; Weber, A.; Wegge, T.; Seitz, G. J. Med. Chem. 2003, 46, 2031.

21. Abreo, M. A.; Lin, N.-H.; Garvey, D. S.; Gunn, D. E.; Hettinger, A. M.; Wasicak, J. T.; Pavlik, P. A.; Martin, Y. C.; Donnelly-Roberts, D. L.; Anderson, D. J.; Sullivan, J. P.; Williams, M.; Arneric, S. P.; Holladay, M. W. J. Med. Chem. 1996, 39, 817. 
22. Manetti, D.; Bartolini, A.; Borea, P. A.; Bellucci, C.; Dei, S.; Ghelardini, C.; Gualtieri, F.; Romanelli, M. N.; Scapecchi, S.; Teodori, E.; Varani, K. Bioorg. Med. Chem. 1999, 7, 457.

23. Romanelli, M. N.; Manetti, D.; Scapecchi, S.; Borea, P. A.; Dei, S.; Bartolini, A.; Ghelardini, C.; Gualtieri, F.; Guandalini, L.; Varani, K. J. Med. Chem. 2001, 44, 3946.

24. Boksa, P.; Quirion, R. Eur. J. Pharmacol. 1987, 139, 323.

25. Dijkstra, G. D. H. Rec. Trav. Chim. Pays-Bas 1993, 112, 151.

26. Chothia, C.; Pauling, P. Acta Cryst. 1978, B34, 2986.

27. Rajur, S. B.; Merwade, A. Y.; Hendi, S. B.; Indian J. Chem. 1989, 28B, 1065.

28. Freed, M. E. U.S. 3317524, 1967; Chem. Abstr. 68:21956.

29. Hlasta, D. J.; Luttinger, D.; Perrone, M. H.; Silbernagel, M. J.; Ward, S. J.; Haubrich, D. R. J. Med. Chem. 1987, 30, 1555.

30. Mokrosz, J. L.; Boksa, J.; Bojarski, A. J.; Charakchieva-Minol, S. Med. Chem. Res. 1993, 3, 240.

31. Fisher, M. H.; Matzuk, A. R. J. Heterocyclic Chem. 1969, 6, 775.

32. Lukas, R. J. In Diversity of interacting receptors; New York, 1995; Vol. 757.

33. Flores, C. M.; Rogers, S. W.; Pabreza, L. A.; Wolfe, B. B.; Kellar, K. J. Mol. Pharmacol. 1991, $41,31$. 